\title{
Diminutives as Intimacy Expressions in English and Armenian
}

\author{
Shushan Khachikyan \\ Yerevan State University
}

\begin{abstract}
Diminutives are an important means of expressing attitudes and emotions in both English and Armenian. Diminutives as intimacy expressions have been much studied in English, meanwhile this aspect of communication has received less scholarly attention in Armenian. The comparative analysis of English and Armenian diminutives carried out in the present paper demonstrates the linguistic differences between Armenian and English diminutive systems, and comes to prove that the conceptualization of intimacy may vary across cultures.
\end{abstract}

Key words: diminutives, intimacy expressions, emotions, attitudes, individual diminutive systems, culture, conceptualization of intimacy.

\section{Introduction}

Traditionally the term diminutive has been used to refer to words that denote smallness, and possibly to express the speaker's attitude which can be positive or negative, depending on linguistic and situational aspects in certain contexts (Schneider 2003). In many cases diminutives are used when talking to children or referring to them. These are nouns indicating children's part of the body, their toys, foods and so on, as well as certain concrete nouns referring to their immediate environment. Diminutive forms are not restricted to interactions with children. It is quite possible that they originated in such contexts, and then developed further to cover similar items of the immediate environment which concern adults. Adults use diminutives when they talk to good friends, parents or grandparents.

Diminutives are most frequently used in situations between close participants in familiar settings, usually at home. However, interactions that occur between strangers in formal institutional contexts, for example, in banks, hospitals or supermarkets, can also be marked by diminutives. The use of diminutives is most often a sign of reduced psychological distance. Thus our aim is to study the linguistic differences between Armenian and English diminutive systems and to show that conceptualization of intimacy may vary across cultures. 


\section{Diminutive Formation in English and Armenian}

Languages are either predominantly synthetic or analytic. An analytic language "is one which either does not combine inflectional morphemes or does so sparingly; grammatical relations are indicated primarily by word order and function words" (Brinton and Arnovick 2006:91). When English creates diminutives, it preferentially does so analytically; that is by compensating for diminutive suffixes lexically, by the addition of analytic markers such as little, tiny or small before the noun (Naciscione 2000:136). Synthetic languages, on the other hand, usually form diminutives through attaching a vast array of diminutive affixes to the root.

English diminutives are not as unique in their extent and variety as Armenian diminutives. They are usually formed analytically and convey diverse meanings. (Wierzbicka 2003; Schneider 2003). Anyhow, English has also plenty of diminutive suffixes that are used in spoken English. Thus, synthetic diminutives do exist in English. In his monograph on diminutives in a corpus of spoken English, K. Schneider discusses diminutive endings such as -ie/-y (in doggie), -let (as in piglet or kinglet), kins (as in the name Lizziekins), -o (as the name Carlo) among many others (Schneider 2003:32).

Analytic diminutives are used comparatively more frequently in English than diminutive suffixes and can convey various expressive meanings. These analytic constructions use the analytic markers little, small, wee, tiny and other adjectives in the semantic field small to convey emotion and smallness (Naciscone 2010).

It may be difficult to pinpoint the diverse meanings of English diminutives but the main analytic markers, little and small, differ greatly from each other. The analytic marker small refers only to smallness, meanwhile little is considered more subjective, more flexible and can express various emotional meanings. The emotive component in the adjective little is supposedly stronger because we can view it as a type of affix (e.g. the Armenian synthetic diminutive unauly could be translated as house-little), while small is more like a word that stands alone, as it does in synthetic languages (e.g Armenian unpp unnı $a$ ).

Diminutives formed with the adjective little and diminutive forms with suffixes do not derive diminutive forms of personal names nearly as much as they do in Armenian, where many diminutive suffixes exist to express various nuances of intimacy (e.g. - $u 4$ - ak, - $h 4-i k,-n l l-u k,-j u l-y a k,-\not h l-l i k)$. English diminutivized names do, however, have a role to play as terms of endearment. There is considerable confusion regarding the difference between English hypocoristics, pet names, diminutive forms, short forms and the amount of emotion they express. For example, the feminine proper name Samantha can be shortened to the hypocoristic form Sam, which, in turn, can receive a diminutive suffix to create Sammie/Sammy or even Sammiekins. A girl named Samantha could also be called little Sam, little Sammy. In this scenario, Sam is the 
standard shortened and truncated form, since the form has lost the last few sounds of the name, while the diminutive suffix -ie creates the diminutive form Sammie.

A girl or woman called Christine would skip Chris and be more likely to be called Chrissy or Christy while a man named Christopher would be called Chris (Bonvillain 2003:82). Therefore, scholars state that an adult named Chris is more likely to be a man (even though women use these shortened form) and an adult named Chrissie/Christy is more likely to be a woman because women are "more likely to be addressed in adulthood with names marked with the diminutive suffix $-i e /-y$ more so than men" (Romaine 1999:56).

Armenian diminutive names, on the other hand, keep a clear difference between feminine and masculine diminutive names. Despite the difference between children's, women's and men's names in English, the affectionate meanings associated with diminutives do not play a vital role as the emotional diminutive meanings conveyed by English diminutives. The -ie suffix tends to be attached to names of small children and sometimes to women's names, while proper names and their shortened forms are used most often among adults/teenagers.

Like English diminutives, Armenian diminutives also convey affection, familiarity and intimacy. Armenian is a synthetic language, yet unı6nıp/4npp - little sometimes forms analytic constructions, such as unı6nıp/Lnpp $+N$, which typically conveys affection or positive diminutive meaning.

Armenian has three basic suffixes that create diminutives: $-h L-i k,-u l-a k,-n ı l-$ $u k$. Added to the noun, they impart the meaning of smallness (in size or value), affection, endearment, but also degradation or debasement on the part of the speaker. The most productive suffix is $-h l-i k$ which is frequently used to form diminutives or hypocorism from nouns. The suffixes $-h l-i k$ and $-n \iota l-u k$ may also be attached to adjectives. When referring to or addressing a person or an object, they indicate affection or fondness: uhpnıG - sirun - uhnnıGhl-sirunik, qkp - ger - qhpnıl-giruk. When the suffix $-h l-i k$ is added to proper names, it expresses the speaker's subjective or emotional attitude toward the person: પuhua -Vahan - પuhuahl - Vahanik, Uuphuu - Mariam - Uuphuuhl - Mariamik, Shqpua - Tigran - Shqnuahl Tigranik. Longer names form diminutives by adding the suffix $-\not l-i k$ to the first syllable of the name.

First names may be morphologically modified with diminutive or augmentative suffixes. For example, the first name UGGu -Anna may be diminutivized in a number of ways: UG-An, Uanı-Anul, UGinцhl-Anulik.

\section{Unique Diminutives in English and Armenian}

Every language has diminutives that are not used in one language or the other. English has a set of diminutives that are connected with garden and kitchen. For 
example, the English diminutives sweetie-pie, cutie-pie, pookie-pie refer to food treats. Pookie-pie is a pet name given to a partner or true love. Typically, most of these diminutives are used to address women, but the Welsh diminutive boyo is primarly used between men.

Diminutives can also have negative connotation. The diminutive poetaster is a word describing an inferior poet. The suffix -aster denoting resemblance, which was common a few hundred years ago, is rare today. The native English suffix -ock is used in such diminutives as hillock, bullock. The French suffix -ette can be seen in such words as cigarette and kitchenette.

Armenians express their love by using diminutives that are closely connected with the concept of life. The Armenian words quahl-janik, hnqjulu - hogyaks which are used as forms of address reflect the spiritual side of diminutives. In fact, qua - jan, which is the most frequently used Armenian word, literally means body or soul.

Armenian diminutives are marked by a large number of animal-related nicknames, for example: mukik - unılhl, ungnıl - arjuk, ánılhl - dzukik, áuqnıl - dzaguk, 2nıGhl-shunik, Lhuhl-pisik, Lhun - piso, qunanıl-garnuk, out of which quunn Lhuhl - Lhhun - katu - pisik - piso, ung - ungnıL - arj - arjuk have the highest frequency in use. In Armenian the name qunahl-Garnik is the diminutivized form of the word qunG - garn. Animal names used metaphorically to address people comprise both positively and negatively connotated expressions. While funq - khoz, uцuaul avanak, 2nıG - shun, huц - hav bear negative connotations, qunGinı - garnuk, ungnıl - arjuk, Lhuhl-pisik have positive connotations.

English also uses a few names of animals, for example lamb, lambie, angel lamb, duck, duckling, pet, petkins, lovey-dovey, honey-bunny. Like diminutives, English animal metaphors are much less productive and are related to animals that have positive connotations and are stereotypically conceptualized as innocent and safe. It may be because English does not have a similar productive category of diminutive that may neutralize negative connotations (Schneider 2003:145).

The main function of diminutives is to signal the speaker's affectionate attitude towards the hearer; hence, they signal psychological proximity between the interlocutors. In particular, affectionate nicknames are characteristic of female conversational style.

\section{Conclusion}

Diminutives form a significant part of the vocabulary of English and Armenian. In both languages diminutives create different meanings and can be formed through synthetic or analytic constructions. Without diminutives language would lose a vital linguistic means of conveying emotion, attitude, evaluation, and, why not, also warmth. Diminutives provide a way to show affection towards people or things; they are 
expressive means and contribute to the emotional aspect of language, whether spoken or written.

The fact that English and Armenian have a set of diminutives which is appropriate to the specific language system comes to prove that every culture constructs its identity around certain shared values which are perceived differently due to the uniqueness of language.

The study of diminutives shows that they can present not only linguistic but also culture-related aspects. Diminutives are more than their semantic meanings, they reflect the unique culture of a language, the writer's individual conceptualization of words, the speaker's preferences. Thus we can conclude that at the core of diminutives lies a deeply embedded cultural worldview.

\section{References:}

1. Bonvillain, N. (2003) Language, Culture and Communication: The Meaning of Messages. N.J: Prentice Hall.

2. Brinton, L.J. and Arnovick L.K. (2006) The English Language: A Linguistic History.Oxford: OUP.

3. Naciscione, A. (2010) Stylistic Use of Phraseological Units in Discourse. Amsterdam: John Benjamins.

4. Romaine, S. (1999) Communicating Gender. Mahwah: L. Erlbaum Associates.

5. Schneider, K.P. (2003) Diminutives in English. Tübingen: Niemeyer.

6. Wierzbicka, A. (2003) Cross-Cultural Pragmatics: the Semantics of Human Interaction. Berlin: Mouton de Gruyter.

\section{Фunup2ulqua puntinn nputiu ưntinunıpjua

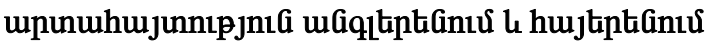

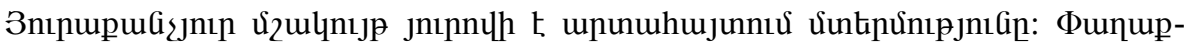

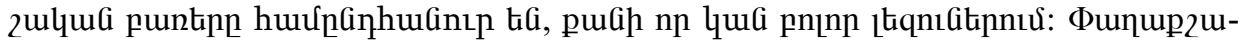

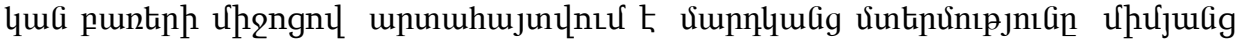

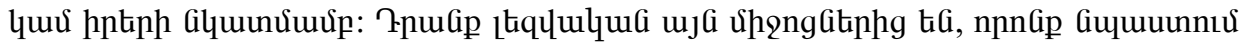

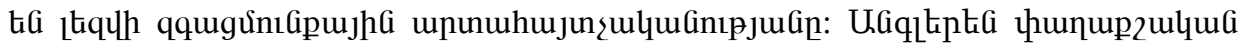

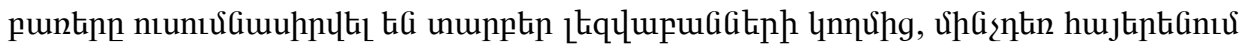

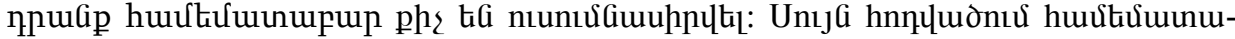

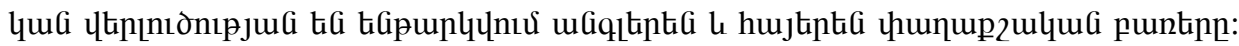

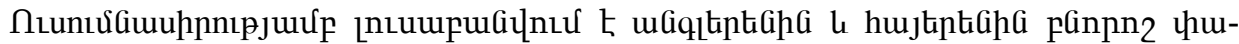

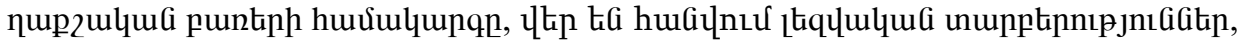

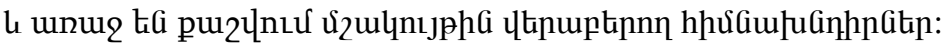




\section{Уменьшительно-ласкательные слова как выражение близких отношений в английском и армянском}

В каждой культуре близость выражается по-своему. В вербальной коммуникации близость выражается уменьшительно-ласкательными словами. Уменьшительно-ласкательные слова дают возможность выразить близость по отношению к людям или к вещам, они являются одним из тех языковых средств, которые способствуют эмоциональной экспрессивности языка. Уменьшительноласкательные слова в английском изучались данной учеными, в то время как в армянском они мало изучались. В статье сравнительному анализу подвергаются уменьшительно-ласкательные слова армянского и русского. Исследованием раскрывается уникальная система уменьшительно-ласкательных слов английского и армянского языков, выявляются не только языковые различия, но и проблемы, относящиеся к культуре. 